\title{
Implementation Of Teacher And Lecturer Policy At Vocation Education System Of The Indonesian Navy \\ Isworo Sutristyanto ${ }^{1}$, Sumartono ${ }^{1}$, Bambang S. Haryono ${ }^{1}$, Lely I. Mindarti ${ }^{1}$ \\ ${ }^{1}$ Brawijaya University, Malang 65145, Indonesia
}

\begin{abstract}
.
Nowadays, the policy of national higher education has an influence on higher education in the Indonesian Navy in patterns and structures, types of education, educational outcomes or graduates of each educational strata. The human resources of the Navy were built by an using expert system with the field of each assignment being scholar soldier, with the development domain is Cognitive, Affective and Psychomotor Domains Granding. The equalization of graduates between academic and vocational education influences on the quantity and quality of standardized military lecturers as educators in the Navy education system which is harmonized with the prevailing national policy. Based on the existing gap due to the implementation of lecturer policy, the efforts that have been done, the purposes of this study are : 1) Describe and analyze the implementation of teacher and lecturer policy on Higher Education Vocation of the Indonesian Navy service vocation; 2) Finds the implementation model of policy of teacher and lecturer in higher education of vocation of the Indonesian Navy. In this research, the paper used Merilee S. Grindle model approach. It model uses to describe the implementation of policy of teachers and lecturers in higher education vocational service of the Indonesian Navy. The result of the policy implementation on vocation system of teacher and lecturer in higher education system of the Indonesian Navy has not given any significant result change, because there are still many obstacles in the process. The model of policy implementation of teacher and lecturer in higher education vocation of the Indonesian Navy officially started by synchronizing policy between the Higher Education Institution and the Indonesian Navy then it is passed down to specific socialization program to support of lecturer policy objectives.
\end{abstract}

Keyword: Public Policy Implementation, Higher Education, Indonesian Navy (TNI AL), Human Resources.

\section{Introduction.}

Higher education is an implementation of a healthy academic climate, and leads to the achievement of a professional academic community (MacNeil, Prater \& Busch 2009). It has an interesting phenomenon to be a research, when it is associated with higher education in the Indonesian Navy (TNI AL).

Competence owned by the Navy personnel is very diverse, this is due to the different fields of duty carried by each personnel of the Navy in the implementation of sea defense. Improving the quality of human resources through education is an absolute requirement (Kadir 2015). Education is a hope to create reliability in an organization (Dirzyte 2013), especially the organization of the Indonesian Navy.

Nowadays, the policy of national higher education has an influence on higher education in the Indonesian Navy in patterns and structures, types of education, educational outcomes or graduates of each educational strata.

The human resources of the Navy were built by using an expert system in the field of each assignment being scholar soldier, with the development domain is Cognitive, Affective and Psychomotor Domains Granding.

The equalization of graduates between academic and vocational education influences on the quantity and quality of standardized military lecturers as educators in the Navy education system which is harmonized with the prevailing national policy.

The gap of research arising from the implementation of this lecturer policy in vocational education of the Indonesian Navy are : 1) The lack of lecturer with master degree with core subject or profession; 2) Giving certification of educator competence from the Ministry of Higher Education; 3) Willingness, time and cost 
for lecturer's research, 3) The necessity of international publication for the result's research, 4) The number of core subject or profession with the lectures of each study program; 5) The policy of assignment of members of the Indonesian Navy in educational institutional of the Indonesian Armed Force; 6) Establishment of organizational structure and lecturer procedure as functional position in Indonesian Naval Academy.

Based on the existing gap due to the implementation of lecturer policy, the efforts that have been done, the purposes of this study are : 1) Describe and analyze the implementation of teacher and lecturer policy on Higher Education Vocation of the Indonesian Navy service vocation; 2) Finds the implementation model of policy of teacher and lecturer in higher education of vocation of the Indonesian Navy.

In qualitative research, the scope of this research is closely related between the formulation of the problem, the objectives of the research and the theory of policy implementation selected according to its elements as follows: 1) the implementation process of teachers and lectures policies, 2) The policy outcome of the impact, 3) Model of policy implementation of teachers and lecturers in Higher Education of Navy service vocational.

The type of research description with qualitative approach where the researcher tries to analyze descriptively about the implementation of lecturer, policy in vocational education of the Indonesian Navy from some aspects such as: lecturers policy objectives.

There are several models of public policy implementation, such as (Marume, Mutongi \& Madziyire 2016) : 1) Model of Mazmanian and Sabatier; 2) Model of Donald Van Meter and Carel Van Horn; 3) Model of Merilee S. Grindle; 4) Model of O'Toole; 5) model of Hogwood et al; 6) model of Merilee S. Grindle.

In this research, the paper used Merilee S. Grindle model approach. It model uses to describe the implementation of policy of teachers and lecturers in higher education vocational service of the Indonesian Navy.

According to Grindle (1980), the success of policy implementation is influenced by two large variables, namely: content of policy and context of implementation.

The benefit inscriptive of this paper is an enriching the analysis and developing the education system in the Navy. Secondly, it gives empirical evidence through a descriptive study of the planning process, the implementation so that the results relating to the implementation of policy teachers and lecturers in the education system in the Indonesian Navy.

This paper is organized as follows. Section 2 presents the experimental framework of Naval Education. Section 3 describes the result of vocational education of Indonesian Navy. Section 4 presents the conclusion of paper.

\section{Material and Method.}

\section{Public policy and Implementation}

Public policy is the biggest challenge in the field of policy implementation. Poor governance can lead to failure in the implementation and development of public policy, even though good administrative / management practices have been implemented (Muhammad 2014). Public policy implementation is dynamic because there are multiple stakeholders and a fragmented approach (Bryson 1995). It is vulnerable to the risks of failure and misery resulting from public expectations and development by state authorities (community leaders) (Crosby 1996).

Some domains of public policy, such as utilities, transport infrastructure, and national security, apply routine logic and technology where raw materials can be viewed, measured, and analyzed and the results are also measured (Hasenfeld 1983). Other policy domains such as social services or economic development often depend on the individual or community attributes that the policy aims, especially when it comes to personnel as the main object and the goal is to change the behavior of individuals through a system (Sandfort 1999). As an academic discipline, public policy integrates other fields of social science such as economics, sociology and management. The development of the literature on Public Policy has been a never-ending process since the start of the concept (Imurana, Haruna \& Kofi 2014). 
According to Thomas Dye (2001), Public Policy is basically "Whatever government chooses to do or not to do". In his view, public policy consists of government actions and inactions. The government's decision not to act is its own public policy. Nevertheless, the government's decision goes through a complex interactive process which is influenced by various characteristics of socio-political factors and other environmental factors (Dye 2001).

The challenge of implementing public policy in developing countries is no other role for civil society in an effort to promote the development that policy-makers have achieved (Thornhill 2009). This becomes a challenge because civil society is acknowledged as a stakeholder to implement effective public policy. According to Masango, it needs to emphasize the importance of public participation in the implementation of a policy (Masango 2007).

\section{Model of Public Policy Implementation.}

Implementation of a policy will certainly take different forms in different cultures and institutional settings. An implementation may mean executing, completing, fulfilling, producing or completing a given task. According to Pressman and Wildavsky, implementation is defined in relation to the policies set out in official documents (Pressman \& Wildavsky 1984).

According to Mazmanian and Sabatier, policy implementation is an implementation of basic policy decisions, relating to legislation, but in the form of executive orders or court decisions (Mazmanian \& Sabatier 1983).

O'Toole defines the implementation of policies as what develops between the establishment of a clear intention from the government doing something or stop doing something and the impact of the action (O’Toole 1995).

Elmore identifies four key materials for effective policy implementation: 1) clear tasks and objectives that accurately reflect the intent of the policy; 2) a management plan that allocates tasks and performance standards to the subunit; 3 ) objective means of measuring subunit performance; and 4) management control systems and sufficient social sanctions to hold subordinates responsible for their performance. Failure of implementation, by definition, deviations from planning, specification and control (Elmore 1979).

According to Hogwood et al, to be able to apply the necessary policy to a certain condition, such as (Hogwood et al. 1984): 1) the external conditions faced by the Agency / Executor; 2) time and resources available; 3) integration of required resources; 4) Implementation based on a reliable causal relationship; 5) direct causality and few links; 6) the dependency relationship should be minimized; 7) a common perception and agreement on goals; 8) tasks arranged systematically and sorted; 9) communication and coordination; 10) the person authorized to claim the compliance of the other party.

Van Horn and Van Meter indentifies eight (8) variables that influence the implementation of public policy programs, likely (Meter, Horn \& Carl 2002): 1) Political environment; 2) Economic and social conditions; 3) Policy standards: clarity, objectivity and tasks; 4) Policy resources: adequacy of funds and incentives; 5) Characteristics of implementing agencies: staff quality, organizational structure and relationships with officials and other units; 6) Implementing disposition: understanding policy standards; 7) Whether the executor is favorably favored or opposed to policy and at what level intensity; 8) Communication: accuracy, clarity and consistency, and enforcement.

\section{Model Merilee S. Grindle.}

The policy implementation model proposed by Merilee S. Grindle is a top-down approach. The basic idea of this model is that once the policy is transformed, policy implementation must be done. In this model, the success of policy implementation is influenced by two major variables, namely: the content of policy and the context of implementation (Grindle 1980).

Content of Policy consists of 6 (six) variables, includes: 1) Interest affected; 2) Type of benefit received by target groups; 3) How far the desired change of the policy (extent of change envisioned); 4) Site of decision making; 5) Whether a policy has specified the implementor in detail (program implementor); 6) Resources committed.

Context of implementation consists of 3 (three) variables, include: 1) Power, interest, and strategies of actors involves; 2) Institution and regime characteristics; 3) Compliance and responsiveness. 


\section{Aspect of Public Policy Implementation.}

There are has many aspects of public policy implementation, such as: 1) Community participatory; 2) Local Surveys and Consultations; 3) Utilization of field officers as a means of participation; 4) Decentralized planning; 5) Local government; 6) Community development; 7) Democracy; 8) Welfare; 9) Collectivity.

\section{The Aim of Teacher and Lecturer Policy.}

The main objective of the lecturer policy is certain to improve the national education system, so it produces the qualified educators and the quality results of the learners as well. Law No. 14 of 2005 in Chapter 2 Article 3 states that the lecturer has a position as a professional at the higher education level appointed in accordance with legislation. The recognition of lecturer's position as professionals is evidenced by the certificate of an educator. The requirements of professional term according to the regulation of the minister of national education of Republic of Indonesia No. 47 of 2009 about educator certification for lecturers 1) have minimum academic education of Master Program for lecturers of Undergraduate Program or Diploma 4; 2) They have done teaching and learning process at least two years; 3) perform Tridharma of education at least 12 Credits System of Semester; 4) They have been posted in academic position as an expert assistant at least with cumulative grade of 160 .

The regulation of the Chief of Staff of the Indonesian Navy, Regulation No.1/I/2011 regarding technical guidance on implementation of educator training of the Indonesian Navy to fulfil the needs of professional educators in order to support the implementation of education, the result of the interview with many lecturers who have not understood the purpose and content of the Law No.14 of 2005. The implementation of teacher and lecturer's policy in the vocational education scope in the Indonesian Navy has not been fully accepted and understood by the policy maker. It certainly requires many efforts in terms of socialization and exposure of the aspects that are able to provide the reinforcement of the main goals of teacher and lecturer policy, as well as the size of of certainty that the main objectives can be implemented and it will give positive results for the development of special education in the field of official vocation education of the Indonesian Navy.

\section{Supported Programs.}

Scholarship programs from Institution Provider of Education Fund, the excellent programs of the Ministry of Education and Culture, Applied Approach (AA), Micro Teaching, Training of Trainer Program (TOT), National Qualification Network, the formation of an education quality institution, accreditation program of institution and study program of the National Accreditation Institution of the Higher Education, Education Cooperation Program. It is seen from the basic leadership function of a leader in educational scope in Indonesian Navy. It has had a role in terms of designing and organizing the support programs for teacher and lecturer policy, the program has not been specially launched in the direction of socialization of teacher and lecturer law, so it is widely estimated that of the educators in the support program and it is considered that the last goal wasn't being clear due to it is only run partially. Then if we look the function of coordination function that runs only within the internal scope of the Indonesian Naval Academy and Education Service of the Indonesian Navy only, but when there is an imbalance in the implementation of policy teacher and lecturer are only limited to become the subject of among the individuals within the scope of internal the Indonesian Naval Academy and the Education Service of the Indonesian Navy institution, but it has not been transparently represented in coordination with the higher policy stakeholder namely the Ministry of Research and Technology of the Higher Institution. Furthermore, the supervisory function runs so far between the Indonesian Naval Academy with the Education Service of the Indonesian Navy only. However, the findings that are inconsistent with the policy of teacher and lecturer do not appear to be reported to higher stakeholder namely the Ministry of Defense and the Ministry of Research and Technology and the Indonesian Navy support the element of education member in the institution, but it hasn't conducted the specification of the program that supports the implementation of teacher and lecture policy.

\section{Result and Discussion. \\ Content of Lecturer Policy.}

There are six policy content variables namely: 1) policy-affected interests; 2) the type of benefits that the target receives immediately are more easily implemented than the symbolic benefits, the collective benefits are more likely to be implemented than the benefits for some targets, the benefit that can be shared and it is 
particularistic. It will sharpen the conflict between the targets; 3) the expected range, for long-term program will be difficult to be implemented than a short-term program. It demands the changes in mindset and behavior which are more difficult to be implemented than physical change; 4) the position of policy maker has dispersed (both geographically and organizationally) so the implementor becomes more difficult to implement, the police maker is close to the government so it is easy to be implemented; 5) the program implementers who have the shortage knowledge and skills and low competence will be very difficult in its implementation; 6) the available resources, the number of types, the amount of the resources deployed strongly influence the implementation of the policy.

How is the interest of the group contained in the content of policy, what interests are affected by this policy, the interest concerning the livelihood of the people is more easily implemented than the interests of any people or group, the interests that can be enjoyed directly by the target are more easily implemented than long-term interests. The real or material importance is more easily implemented than symbolic and prestigious. If the policy objectives can be realized then the lecturers who meet the established national standard having the competence of teaching which is appropriate to the background of their science, they must have a National Lecturer Number so they have a lecturer colloquium, they must have the academic rank according to the cumulative score of the expert assistant, associate professor, senior associate professor, all of which are symbolic and pride, so it needs the efforts to increase the motivation to make professional lecturer. Due to the matter, the interests on the impact such as the interests of cadets and the interests of the institution are still difficult to be fulfilled.

The types of benefit directly accepted by the target are easier to be implemented than symbolic benefits, the more important of the collective benefits may be implemented than the benefits for some target. The particularized benefits that can be shared will sharpen the conflict among the targets. The direct benefit of the nationally recognized lecturer, the institution has national standard lecturers, students, lectures and the institution should have the facilities for self-development in accordance with the outside lecturers. The facility for research has not been provided by the Minister of Research and Technology of Higher Education yet. It needs a coordination and a synchronization so that the functional lecturer at the Indonesian Naval Academy is equal, so it doesn't weaken its implementation.

The desired degree of change is to make a professional lecturer of the Indonesian Naval Academy. A such change can be viewed from a perspective locus such as the environment of the lecturer, the scope of education institution. From the perspective of affective or attitude can be reviewed from the behavioral dimension, attitude and work ethics, appearance, knowledge, method of teaching etc. The changes in attitude and behavior of the lecturers will be difficult to be implemented comparing with the degree of change that is the nature of knowledge, material, or teaching methods. The statement of Chief of Education Service of the Indonesian Navy has a value that the Indonesian Navy desires a change of the determined Law No. 14 of 2005 concerning teacher and lecturer gradually and continuously starting from the absence of a lecture certificate owned by the lecturers, there is not an accurate size at what level, then it will be obtained by the lecturer and then it continues to the next level so that it will be achieved a qualification in time, competence and certification at the highest level. The change that is not visible such as work attitude, motivation of teaching, morale, they cannot be grown in the lecturers of the Indonesian Naval Academy if there is not a real sanction or reward in reality, this policy is weak for its implementation.

The position of the policy maker is crucial to the successful implementation of a policy, the position referred to this element is the proximity of this policy maker with central power, his position directly regulates from the institution, the target group that becomes the object of the law in this policy, such as the lecturers of the Indonesian Naval Academy are very respectful if the policy maker is the Indonesian Navy that has a full authority over the lecture's career in the Indonesian Naval Academy. The result for policy maker focuses only on the Personnel Assistant to the Chief of Staff of the Indonesian Navy. In this case, Head of Education Service of the Indonesian Navy is the policy maker. The position of the policy maker at the control of power, and it must be implemented by all lecturers in an educational institution, either under the Higher Institution or other institutions. It needs to coordinate and synchronize the content of the policy to facilitate the implementation of content and policy objectives.

The mobilized resources include the personnel resources, facilities and infrastructure, and instructional tools, the resources of the main defense system, financial resources, authority resources, and power resources. 
Related to the personnel resources, educators owned by the Indonesian Naval Academy currently are 180 personnel in the strata of the Indonesian Armed Force as well as Civil Servant with various disciplines and qualifications. From the total number of the educators who are owned by the Indonesian Naval Academy, only about 154 personnel who have Applied Approach certification standard and Micro Teaching and Educator Technical Course and the lecturers who have a National Lecturer Number are 40 personnel, 20 personnel have taken the Master's Program and 2 personnel have taken the Doctorate Program. If the grant of a lecturer certification is given to all eligible of the Indonesian Navy members in accordance with this policy, Indonesian Naval Academy will be free to provide the lecturers from the side command in accordance with their expertise due to it is motivated by the lecturer certification allowance.

\section{Implementation Content.}

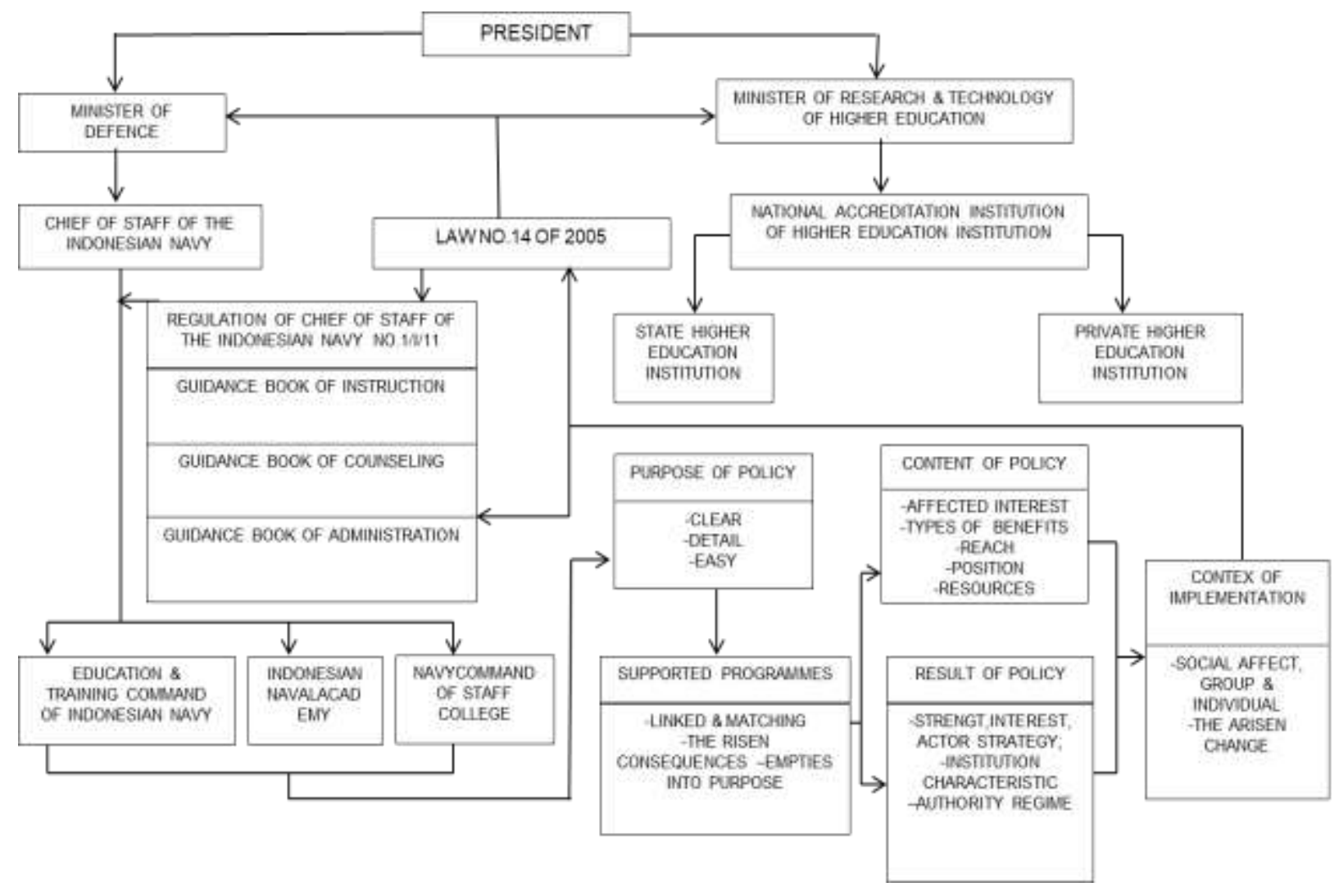

Figure 1. The Model of Teacher and Lecturer Policy Implementation in Vocation Higher Education for the Indonesian Navy (TNI AL).

a) Authority, interest and the involved actor strategy.

The number of policy actors who are involved and the interests of the program implementation, it will be more complicated and making decision. The interested actors are the Chief of Education Service of the Indonesian Navy, Indonesian Naval Academy and the lecturers of the Indonesian Naval Academy for accreditation of study programs and accreditation of the Indonesian Naval Academy to obtain National Number of Lecturer and lecture certification when they are given the opportunity, it is just for recognition and it is used for teaching outside, higher institution, personal interest, whlile they haven't got certification allowance, they have received the performance allowance. The strategies undertaken by each service. In this case, Education Service of the Indonesian Navy, the accreditation process of the study program and institution as submitted to each educational institution. As for the management of National Number of Lecturer, each lecture is actionable to meet the requirements and by the administration of Higher Education Database, the 
requirements must be uploaded. Due to the Education Service of the Indonesian Navy is the central executive institution of the Indonesian Navy under the Chief of Staff of the Indonesian Navy. The duty of Education Service of the Indonesian Navy is to organize the development of education functions including the analysis of needs, educational planning, educational development and operations education and supervision, control and evaluation of education in the Indonesian Navy. " The Chief of Staff of the Indonesian Navy has the highest role and authority in the implementation process of Law No. 14 of 2005 on teacher and lecturer in the scope of the educational institution of the Indonesian Navy".

\section{b) Characteristic of institution and authority}

The capabilities and characteristics of the involved ruler/regime in the interaction of policy implementation make easier in searching for opportunities to achieve the objectives of the programs and the policy. The assessment of the powerful capabilities of the implementor actor, the nature and the sensitivity of the Indonesian Naval Academy organization is an integral whole, and it is difficult to change because it is so strongly held by the members of the Indonesian Navy. This phenomenon can be observed in daily life where the values of the belief and the assumptions in the organization of the Indonesian Naval Academy. This is motivated by the nature of military culture itself which requires a high discipline in implementing both of the written rule and unwritten rule. How far the academic situation has achieved the ideal quality level, then it can be measured by the embodiment of academic culture that puts forward the value and academic ethics of all Civitas Academica of the Higher Institution. How far the academic situation has achieved the ideal quality level, then it can be measured by the realization of academic culture that puts forward the academic ethics values from all civitas academica of the Higher Institution.

c) Compliance and implementer response

Compliance, consistency of implementor with the goals and the objectives of the program greatly affects the success of the program, the responsiveness to change the attitude of the disadvantaged party to be the motivator of the program achievement. The compliance level of the implementer on the mandate of the is still not applied properly. Although it needs to re-examine the causes making the implements of the policy are not not compliant due to there is still discrimination to the prevailing of the law without a chance to be given the opportunity to take the lecturer certification exam for lecturer and without giving the certification allowance.

\section{Policy result}

The implementation of this policy to teacher and outside lecturer as mandated by Jateng Hery Nugroho" It doesn't show to the teacher as a profession, but puts teacher as laborer" because the teaching task is more than 24 to 40 hours with face-to-face, it doesn't include the other activities such as planning a lesson, implementation of learning, assessment of learning outcomes, guiding and training learners, as well as carrying out the additional tasks, so the teacher and lecturer don't have time to develop the profession and competence, if they are only still busy teaching.

There has not been a significant change in the Indonesian Naval Academy in the policy result due to the discrimination in the implementation of the policy, so that the impact is weak on its implementation.

\section{Conclusion.}

The implementation of the policy of teacher and lecturer in the vocation higher education of the Indonesian Navy service is still difficult to be done due to the low response and non-compliance of the implementer and the gap between the stakeholder of higher education policy of the Indonesian Navy with the Higher Education in the frame of the competence standardization preparation of educators and instruments and their right and obligation. The result of the policy implementation on the vocational system of teacher and lecturer in higher education system of the Indonesian Navy has not given any significant result change, because there are still many obstacles in the process.

The model of policy implementation of teacher and lecturer in higher education vocation of the Indonesian Navy officially started by synchronizing policy between the Higher Education Institution and the Indonesian Navy then it is passed down to specific socialization program in support of lecturer policy objectives. 
This paper supported by Brawijaya University and The Indonesian Navy.

\section{References.}

[1] Angus J. MacNeil, Doris L. Prater, and Steve Busch, "The Effects of School Culture and Climate on Student Achievement," International Journal of Leadership in Education, vol. 12, no. 1, pp. 73-84, 2009.

[2] M. A. Kadir, "Structuring the Human Resources (HR) Featured In Building Independence Small and Medium Enterprises (UKM) in Makassar," International Journal of Advanced Research, vol. 3, no. 4, pp. 390-398, 2015

A. Dirzyte, "Research on Positivity and Psychological Capital at Science and Study Institution in the USA," Intellectual Economics, vol. 7, no. 3, pp. 389-395, 2013.

[3] S. B. M. Marume, Chipo Mutongi, and N.C Madziyire, "An Analysis of Public Policy Implementation," IOSR Journal of Business and Management, vol. 18, no. 4, pp. 86-93, 2016.

[4] F. Muhammad, "Leadership, Governance and Public Policy Implementation Competencies in the Broader Public Sector," European Journal of Business and Management, vol. 6, no. 36, pp. 66-74, 2014.

[5] J. Bryson, Strategic Planning for Public and Nonprofit Organization: A guide to strengthening and sustaining organizational achievement. San Francisco: Jossey-Bass, 1995.

[6] B.L. Crosby, "Policy implementation: The organizational challenge," World Development, vol. 24, no. 9, 1996.

[7] Y. Hasenfeld, Human Service Organizations. Englewood Cliffs: Prentice Hall, 1983

[8] J. Sandfort, "The Structural Impediments to Human Service Collaboration: The Case of Frontline Welfare Reform Implementation," Social Service Review, vol. 73, no. 3, pp. 314-339, 1999.

[9] B. A. Imurana, R.i K. Haruna, and Annin-Bonsu N. Kofi, "The Politics of Public Policy and Problems of Implementation in Africa: An Appraisal of Ghana's National Health Insurance Scheme in Ga East District," International Journal of Humanities and Social Science, vol. 4, no. 4, pp. 196-207, 2014.

[10] T. R. Dye, Top-Down Policymaking. New York: Chatham House, 2001.

[11] C. Thornhill, "Local government's contribution to a sustainable developmental state," Administratio Publica, vol. 7, no. 3, pp. 24-44, 2009.

[12] R. S. Masango, "Role of public opinion in the governance of a democratic state with reference to South Africa," Journal of Public Administration, vol. 42, no. 5, 2007.

[13] J. L. Pressman and A. Wildavsky, Implementation: $3 r$ edn. Bekeley: University of California Press, 1984.

[14] D.A. Mazmanian and P.A Sabatier, Implementation and Public Policy. Glenview: Scott, Foresman, 1983.

[15] L.J.R. Jr. O’Toole, "Rational Choice and Policy Implementation," American Review of Public Administration, vol. 25, no. 1, pp. 43-57, 1995.

[16] R. F. Elmore, "Backward Mapping: Implementation Research and Policy Decisions," Political Science Quarterly, vol. 94, pp. 601-616, 1979.

[17] Hogwood, Brian W, Gunn, and A. Lewis, Policy Analysis for the Real World. Oxford: University Press, 1984.

[18] Van Meter, Van Horn, and E. Carl, "The Policy Implementation Process : A Concentual Framework ," Administration and Society, vol. 6, no. 4, pp. 445-485, 2002.

[19] M. S. Grindle, Politics and Policy Implementation in The Third World. New Jersey: Princnton University Press, 1980. 